\title{
Erratum to: Effects of forest taxation and amenity preferences on nonindustrial private forest owners
}

\author{
Sepul K. Barua $\cdot$ Jari Kuuluvainen • \\ Jani Laturi · Jussi Uusivuori
}

Published online: 26 November 2009

(C) Springer-Verlag 2009

\section{Erratum to: Eur J Forest Res}

DOI 10.1007/s10342-009-0310-6

The second sentence in 'Discussion and conclusions' in the original publication reads 'The profit tax tends to increase the total harvests while the land value tax tends to decrease them.' It should actually read 'The profit tax tends to DECREASE the total harvests while the land value tax tends to INCREASE them.'

The online version of the original article can be found under doi:10.1007/s10342-009-0310-6.

S. K. Barua $(\bowtie) \cdot$ J. Kuuluvainen

Department of Forest Economics, University of Helsinki,

P.O. Box 27, Latokartanonkaari 7, 00014 Helsinki, Finland

e-mail: sepul.barua@helsinki.fi; sepul175@gmail.com

J. Kuuluvainen

e-mail: jari.kuuluvainen@helsinki.fi

J. Laturi · J. Uusivuori

Finnish Forest Research Institute (METLA),

Vantaa Research Unit, PL 18, 01301 Vantaa, Finland

e-mail: jani.laturi@metla.fi

J. Uusivuori

e-mail: jussi.uusivuori@metla.fi 